\title{
A SCOPING REVIEW OF FINANCIAL THEMES IN ENTREPRENEURIAL ORIENTATION
}

\author{
Al-Mutawakkil Fadhilah Laiela*, Purnomo Margo, Maulina Erna \\ Department of Business Administration, University of Padjadjaran, Indonesia \\ *E-mail: fadhilah17005@mail.unpad.ac.id
}

\begin{abstract}
The purpose of this article is to conduct a scoping review of financial themes within the context of entrepreneurial orientation. Entrepreneurial orientation has a crucial role for companies that want to succeed in today's dynamic business environments, while finance is a crucial resource that will be wont to capture a business opportunity. The scoping review is a sort of literature search with certain important differences from the literature review. Systematically, the scoping review explores the literature from a relevance standpoint instead of evaluating the quality of the research. Then the data are mapped to spot key themes and gaps within the literature. We observe that the financial theme discussed in entrepreneurial orientation is access to financial resources, financial resources, financial orientation, and financial performance. We also observe that the majority of the research is completed in Europe, Asia, and Africa. Finally, we observe that most research methodologies used are mainly supported by quantitive methods.
\end{abstract}

\section{KEY WORDS}

Entrepreneurial orientation, financial themes, literature review, scoping review.

Various firm strategies are the company's effort to get the required business capital in completing and expanding its business. Effective strategic orientation can make the corporate gain more return and profit and attract more external financial. Furthermore, Aktan and Bulut (2008) in their research suggest that strategic activities positively affect the company's financial access within the future. However, operations and strategic activities of the corporate that determines the company is capable or not in obtaining sufficient financial resources (Mazanai \& Fatoki, 2012). Therefore, a strategic orientation configuration operation can allow the corporate to draw in external investors.

Several previous studies have introduced access to finance as a variable mediator. For instance, a study by Zampetakis et al. (2011) which tests the relationship between entrepreneurial orientation, access to financial resources, and broadcast product performance. The results show that access to financial resources fully mediated the impact of entrepreneurial orientation on product performance. Likewise, Fatoki (2012) investigates the impact of entrepreneurial orientation on access to debt financing and the performance of small and medium enterprises (SMEs). The results also show that access to debt financing partially mediated the relationship between entrepreneurial orientation and SME performance. As a result, supported by these arguments and previous research findings, there is an opportunity that entrepreneurial orientation features a significant relationship to financial access and may directly improve the company's performance. However, studies discussing and proving that entrepreneurial orientation will improve access to finances and ultimately increase performance is restricted in number. On the other hand, entrepreneurial orientation in some another study did not have a big impact on the company's performance (Khalil, Nejadhussein \& Fazel, 2013). This suggests that entrepreneurial orientation does not directly impact business performance (Lumpkin \& Dess, 1996; Wiklund \& Shepherd, 2005).

In this study, researchers will map to identify financial themes and gaps within the entrepreneurial orientation literature. This study is performed to explores the literature from a relevance standpoint of financial themes within the context of entrepreneurial orientation, without evaluating the quality of the research. Basically, the purpose of this article is to conduct a scoping review of financial themes within the context of entrepreneurial orientation. 
The scoping review method will give information obtained from previous research, therefore research offers advice supported research and empirical research.

\section{LITERATURE REVIEW}

Financial literacy is the ability to form judgments and effective decisions regarding the utilization and management of money (Noctor et al., 1992; Beal and Delpachitra, 2003). Financial literacy can also be defined as part of the essential knowledge that people got to survive in modern society (Kim, 2001). Financial literacy refers to an individual's ability to know and make use of financial concepts (Servon and Kaestner, 2008). Financial literacy consists of two dimensions, knowledge and application (Huston, 2010), and it encompasses knowledge and cognitive skills with a set of desirable attitudes, behaviors and external enabling factors (Lusardi, 2012).

Financial literacy is assumed to be a valuable resource for creative firms. It enables entrepreneurs to avoid business failures caused by poor financial management (Berryman, 1983). Moreover, studies by the Global Entrepreneurship Monitor (GEM) 2010 show that the shortage of financial literacy is one of the common deficiencies among small business owners which contributes to the high failure rate of small businesses. Financial literacy is reported to possess a positive impact on small and medium firms' performance in various regions (Barte, 2012; Wise, 2013; Siekeietal., 2013).

Access to financial resources allows firms to convert financial resources into physical or human resources with relative ease in order to realize business goals (McCarthy et al., 2017; Moreno and Casillas, 2008). Several authors argue that greater access to financial resources inhibits EO because firms could also be less stimulated to experiment or undertake new initiatives and should not consider it necessary to take advantage of new entrepreneurial opportunities (George, 2005). Essentially, easy access to financial resources intensifies risk aversion which promotes an attitude of low exploration, passive responses to market opportunities (Voss et al., 2008), and managerial complacency (George, 2005). Additionally, easy access to financial resources may cause excessive optimism during a drive to implement the incorrect strategic actions (De Meza and Southey, 1996). This is often associated with overconfidence about the duration and viability of projects, as well as continued strategic actions despite negative outcomes (George, 2005). However, access to financial resources may be a critical resource for firm growth and survival due to its impact on the firm's capacity to take a position in projects. Indeed, easy access to financial resources may hinder capital restrictions and permit the firm to form better strategic investment decisions (George, 2005). This is often even more important for family SMEs, as they typically suffer from a scarcity of resources (Chandler and McEvoy, 2000). Therefore, easy access to financial resources can help firms experiment with new strategies and innovations, thereby stimulating firm innovativeness (Wiklund and Shepherd, 2005).

Funds are important resources that will be wont to capture business opportunities (Rita, Wahyudi, \& Muharam, 2018). The weaknesses of entrepreneurs' capabilities in recognizing competitive financing opportunities that are appropriate with a company's cyclical needs can affect financial decision making that is not very optimal for the enterprise. Courage is required to take risks, also as have a proactive and innovative attitude in making company financial decisions, whether when using internal or external financial capital. The availability of financial capital is vital throughout the corporate cycle. Every firm features a different financial pattern for all of its life cycle stages, beginning from the start-up stage until the mature stage (Koch, Kuhn, Gruenhagen, \& Hisrich, 2010; Xiao, 2011). This fact is due to the various conditions in each stage of a business cycle. If an entrepreneur is unable to acknowledge a financing pattern, it will cause failure within the firm. This suggests that financial problems are connected with the entrepreneurial aspect of an entrepreneur.

Financial resources can sometimes structure for other sorts of resource constraints (Wiklund \& Shepherd, 2005), for they affect innovativeness, proactiveness, and risk-taking (Burgelman \& Välikangas, 2005; Eisenmann, 2006). Pursuing entrepreneurial business 
strategies requires considerable financial capital. For small firms especially, access to financial resources appears to be fundamental but difficult (Wiklund \& Shepherd, 2005).

Fritz (1996) notes financial orientation is so associated with production and cost orientation. Regarding at business unit level, aims are liquidity, profit, return on investment, and financial independence. At the corporate level, financial orientation is described by investment and disinvestment strategies in managing a portfolio of business units.

Financial orientation may be a strategic management approach to decision-making with emphasis on financial performance measured in terms of profitability, and "bottom-line" performance within the short term. The essential thrust of a financial-oriented strategy is to specialize in financial ratios and other measures (Masterson and Pickton, 2004) to reduce costs, and to provide an adequate return on the stockholders' equity (Beatty, 1988). Thus, firms are "seeking ways to minimize overhead costs, to eliminate intermediate production steps, to reduce transaction and other 'friction' costs, and to optimize business processes across functional and organizational boundaries" (Treacy and Wiersema, 1993, p.85).

A firm's finances and operations are integrally connected. Studies have shown that the concept of corporate performance is multidimensional in nature (Venkatraman and Ramanujam 1986). Within corporate performance, the main target has always been on the financial side, hence it is traditionally defined in financial terms. Additionally, investors, shareholders and other stakeholders have an interest in to urge information about the firms' performance conditions frequently. Financial information (ie. return on investments, return on equity, growth of sales, profitability, etc.) is that the most extensively explicit and valid information among the opposite performance dimensions. On the other hand financial information should even be available particularly for regulatory and supervisory bodies for auditing certain fiscal issues and taxations. The extent to which this financial information should be disclosed depends upon the firms' characters -i.e. being a private or public character of a firm, its size, or the company's being listed or unlisted.

Financial performance refers to a firm's ability to get new resources from day to day operations over a given period of time. The financial performance measures are often divided into two major types: (1) traditional measures supported accounting/financial data (i.e. the effect of actions on one year's profits, ROI, ROE, etc.) which reflect a firm's past performance; and (2) market-based measures derived from stock market values (i.e. Stern Stewart \& Co.'s Economic Value Added [EVA] and Market Value Added [MVA] approaches) which are supported valuation principles.

The research topic in entrepreneurship has emerged since decades ago. Roles of supplying entrepreneurship (Covin, Green, \& Slevin, 2006; Lumpkin \& Dess, 1996) was widely studied within the last 10 years. According to Lumpkin \& Dess (1996) supplying entrepreneurship may be a strategic level company that captures the practice of creating organizational strategy, managerial philosophy, and corporate behavior is the natural nature of entrepreneurs.

Entrepreneurial orientation developed by Miller (1983). Miller's Research (1983) focuses on the organizational tendency to venture creation. The goal of developing this concept is to supply the proper framework for research on entrepreneurship. Later, Covin and Slevin (1988) defined the EO more comprehensively on the idea of Miller's research as "Entrepreneurial orientation of the corporate demonstrated by the extent to which top managers tend to take business-related risks (dimension Risk-taking), to support change and innovation to gain a competitive edge for their company (dimension of Innovation), and to aggressively compete with other companies (proactive dimensions)".

Two additional dimensions of EO, autonomy and competitive aggressiveness are incorporated by Lumpkin \& Dess (1996). They need the view that these five dimensions are necessary to define the EO concept comprehensively. They define the EO as "processes, practices, and decision-making activities that cause new entry ". This definition differs from those given by Covin and Slevin (1988), as this definition has considered strategic decisions of organizations that stimulate new entries.

The research question within this research is "How is financial literature on entrepreneurial orientation standpoint?". The answer to this question will discuss and contain 
all of the financial themes from an entrepreneurial orientation standpoint. It will discuss financial resources (internal and external financing), how to get and access financial resources, how to manage the financial resources to be effective and efficient, which finally leads to improving the firm's performance. The objective of this study and its research question is to provide an overview or scoping of the type, extent, and quantity of research available in the current financial literature related to EO. This scoping review will examine the academic literature as it relates to finance and $\mathrm{EO}$ and tease out themes and common ideas. As part of the scoping study methodology, the scoping survey will review articles exploring the EO concept. Exploration of this kind may help to surface gaps in the literature that would need addressing and where no gaps are clearly identified, common trends can be described (Arksey \& O’Malley, 2005).

\section{METHODS OF RESEARCH}

The scoping review is a sort of literature search with certain important differences from the literature review. Systematically, the scoping review explores the literature from a relevance standpoint instead of evaluating the quality of the research. This addresses the exploratory nature of a scoping review. Then the data are mapped or charted to spot key themes and potential gaps within the literature. Finally, a consultation process with the topic matter or contextual experts is often optionally wont to validate the findings (Arksey \& O'Malley, 2005). Arksey and O'Malley (2005) specify five stages to the scoping review. These stages are going to be integrated throughout this article: "identifying the research question" (p. 23), "study selection" (p. 25), "charting the data" (p. 26), collating and reporting on the results (p. 27). There is a final and optional step of consulting a topic matter expert which will be used if the remaining themes and issues do not identify a gap within the literature (p. 28).

We started the scoping review with a literature search that was conducted to spot peerreviewed, English language, academic literature that was relevant to this article's question. Boolean search expressions, as shown in Figure 1, were wont to narrow the search results.

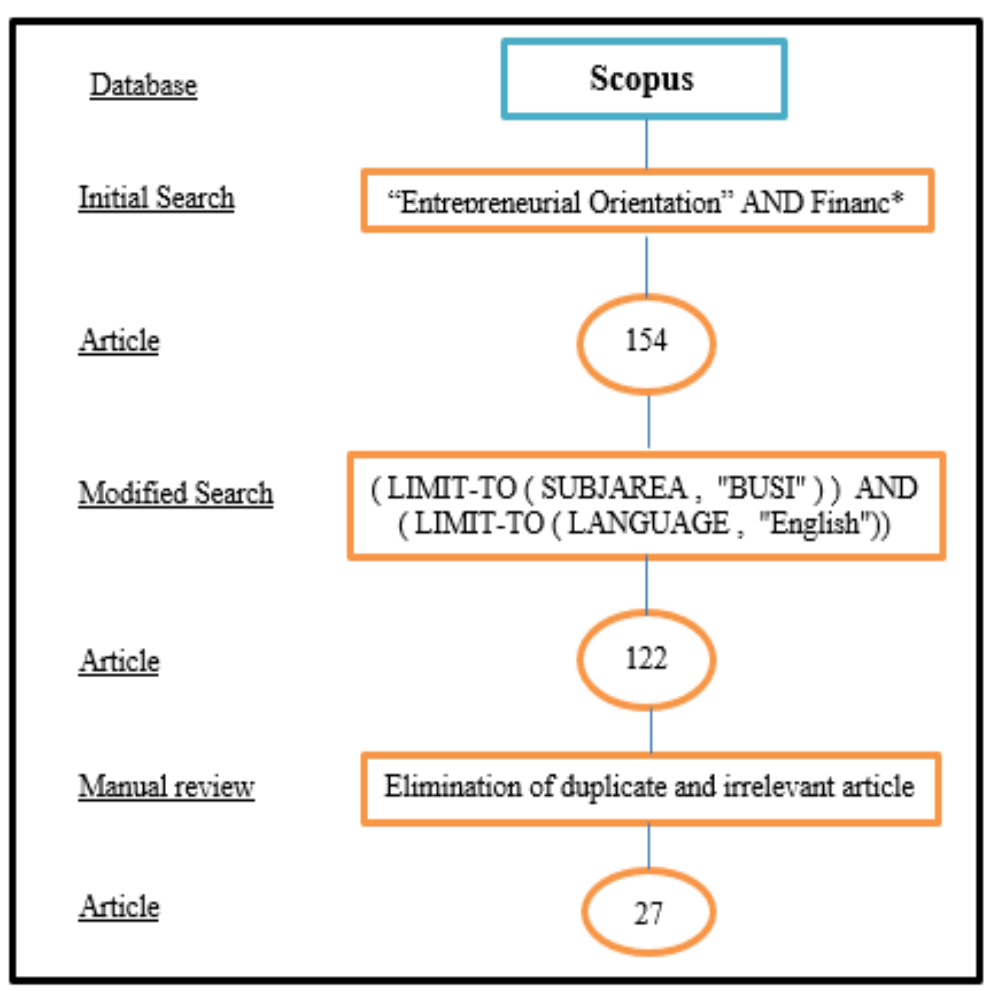

Figure 1 - Scoping review search methodology 
Table 1 - Summary of Selection of 27 Research Articles on Finance Within EO Context

\begin{tabular}{|c|c|c|c|c|c|c|}
\hline \multirow{2}{*}{ Financial Themes } & \multicolumn{3}{|c|}{ Type of research/methodology } & \multicolumn{2}{c|}{ Entrepreneurial Orientation as } \\
\cline { 2 - 7 } & Quantitative & Qualitative & Mixed-methods & Conceptual & Antecedent & Consequent \\
\hline Financial Resources & 11 & 0 & 1 & 1 & 10 & 3 \\
\hline Access to Financial Resources & 3 & 0 & 0 & 0 & 0 \\
\hline Financial Orientation & 1 & 0 & 0 & 0 & 1 \\
\hline Financial Performance & 5 & 1 & 1 & 0 & 7 \\
\hline Financial Literacy & 2 & 0 & 0 & 0 & 0 \\
\hline
\end{tabular}

The initial search used terms that were wont to represent Financial Themes with the "AND" Boolean operator to capture all of the available literature within the searched databases, using the term "Entrepreneurial orientation" to represent EO. From the initial results, we used the term "Business, management, and accounting" focused on articles that were more concerned about business, management, and accounting as a subject area instead of general papers. We stayed and focused on the search results from the SCOPUS database search engines to make sure that papers focused on both issues of finance and EO could be selected.

Subsequently, the papers were reviewed for duplication and for papers that undefined. Their research methodology and therefore the way that financial themes were used within the paper were listed. Similarities and themes from the theoretical viewpoint were teased out and reviewed. Financial themes articles were grouped according to the five financial themes that were described within the introduction: financial literacy in EO (Purnomo, 2019; Zabelina et al., 2019), financial resources can be as dependent and independent variables in EO (Kallmuenzer et al., 2019; Vaznyte and Andries, 2019; Beltrame et al., 2018; Wales et al., 2018; Brzozowski et al., 2018; Beliaeva et al., 2018; Šarlija \& Pfeifer, 2018; Bessière et al., 2017; Silver et al., 2016; Boso et al., 2016; Rank et al., 2015; Soininen et al., 2015; Filser et al., 2014), access to financial resources can be as dependent and independent variables in EO (Arzubiaga et al., 2018; Olutuase et al., 2018; Ibrahim \& Shariff, 2016), financial orientation as dependent variabel in EO (Tajeddini, 2015), and financial performance as dependent variabel in EO (Cheah, Amran, and Yahya, 2019; Khanagha, Dehkordi, Zali and Hejazi, 2018; Adomako, 2017; Núñez-Pomar et al., 2016; Shahzad et al., 2016; Sürer and Mutlu, 2015; Wales et al., 2013). The themes listed in Table 1 were determined from reading the articles.

\section{RESULTS AND DISCUSSION}

The results described in Table 1 shows five financial themes within the field of EO and therefore the methodology used by the researchers. Research questions were listed and whether the EO referred to as antecedent or consequent and listed within the appendix. As suggested by the scoping review methodology, the articles were not analyzed in depth apart from their initial categorizations (Arksey \& O'Malley, 2005).

Our first observation is that there is almost an equal number of articles for every financial theme, indicating a spread of opinions about how finance is considered. This is in line with general financial literature where finance is modeled as predictors, outcomes, or as the relationship between parties. Our second observation is that the research methodology utilized during this field is based on quantitative methodology with three articles using qualitative methodology and one article of a conceptual nature. Most of the articles used a survey methodology to explain or explore issues associated with finance. This sort of quantitative methodology is expected around emerging issues and theories. Given that several of the reviewed papers have focused on finance as dependent variables or independent variables (outcomes or predictors), in EO.

Another observation is that most of the research is based in the United State, Europe, Asia, and Africa with two article's research originating in Ghana and another spread all over European and Asian countries. The financial themes contain financial cycles from financial resources, how to get and access to financial resources, then how to manage the financial resources to be effective and efficient, finally result in financial performance. This makes 
logical sense as this literature deals with the scope of EO that tends to be related to small firms.

In the next stage, an iterative process as described in the scoping review methodology (Arksey \& O'Malley, 2005) was applied to the research results to view the results through the lens of different management theories. List of topics below indicate the main management theories discussed in the articles as detailed in the appendix. The earliest published articles were from 2013 which indicates a young research area. Certain theoretical areas are represented more frequently: Behavioral theory, stakeholder theory, Culture-centric innovation theory, Dynamic capability theory, Pecking Order Theory, Regulatory focus theory, Structural contingency theory, The signaling theory, Theory of arbitrage capital, Theory of organizational culture and economic responsibility theory. Mainstream theories such as Resource-Based View (RBV) theory and entrepreneurship theory have previously been advanced as important theories to consider in the consideration of EO.

List of Theories Discussed in Selected Articles:

- Behavioral theory;

- Culture-centric innovation theory;

- Dynamic capability theory;

- Entrepreneurship theory;

- Institutional theory;

- Pecking Order Theory;

- Regulatory focus theory;

- Resource-Based View (RBV) theory;

- Screening theory;

- Structural contingency theory;

- Stakeholder theory;

- The signaling theory;

- Theory of arbitrage capital;

- Theory of organizational culture.

The purpose of this study was to provide an overview of the type, and quantity of research available on current financial literature related to EO through a rapid gathering of literature and mapping of the results. Arksey and O'Malley (2005) introduce this technique as one that identifies research gaps without necessarily commenting on the quality of the extant research. Davis, Drey, and Gould (2009) suggest that the limits of the technique be clearly specified to improve the usefulness and applicability of the results. In the following discussion, the results will be analyzed and the limitations of the analysis will be presented.

This scoping review looked at finance in entrepreneurial orientation and determined that this field of study has not been extensively researched. Of the 154 peer-reviewed articles dealing with finance and some version of EO terminology, only 27 relevant articles were found from a search of the Scopus databases that integrated both concepts. Our search methodology could have missed papers that did not describe finance and EO within the number of words and with the terminology for EO that were defined in our search algorithm.

Our search methodology also included a manual revision of the 122 articles that were generated prior to narrowing the relevant articles to 27 (shown in Figure 1). During this revision, we were subjective in our interpretation of both the context of EO and how finance was described within this context. As a limitation of this review, it is possible that we may have excluded some of the articles because of their marginal inclusion of finance or the marginal context of EO according to our interpretation of the concepts.

We found that there are gaps relating to the inclusion of theories that are described in the financial literature resulting from our search. The result shows that most of the researchers use behavioral theory, pecking order theory, and signaling theory in their research. These theories are related to get and manage funding potential. Moreover, the results of the scoping survey show that financial themes in the EO context may derive more of its work from theories related to entrepreneurship such as entrepreneurship theory, and 
resource-based view (RBV) theory.

This scoping review reveals that the literature on finance of EO is still scarce. The extant financial themes within the EO context make the cycle and relate to each other. There are five big themes that discuss finance. The first theme is financial resources (FR) divided into two resources: internal and external resources. The second theme is access to financial resources (AtR) that explain and more focus on how to get external financial resources. The third theme is the financial orientation (FO) that describes how to manage the company resources to be effective and efficient. The fourth theme is financial performance (FO) that describes how well a firm can use assets from its primary mode of business and generate revenues. The term is also used as a general measure of a firm's overall financial health over a given period. The fifth theme is financial literacy ( $F L)$ that explains the ability to make judgments and effective decisions regarding the use and management of money. This last theme includes all four themes previously. The relationship of the theme is described and shown in figure 2.

We found that the articles selected did not specifically focus on defining finance except for the article by Wales, Cox, Lortie, and Sproul (2019) who defined investment steps in the decision-making process (p. 2). We found that the other articles focused on financial literature as a predictor or outcome in the EO context rather than focus on the conceptual definition of financial literacy.

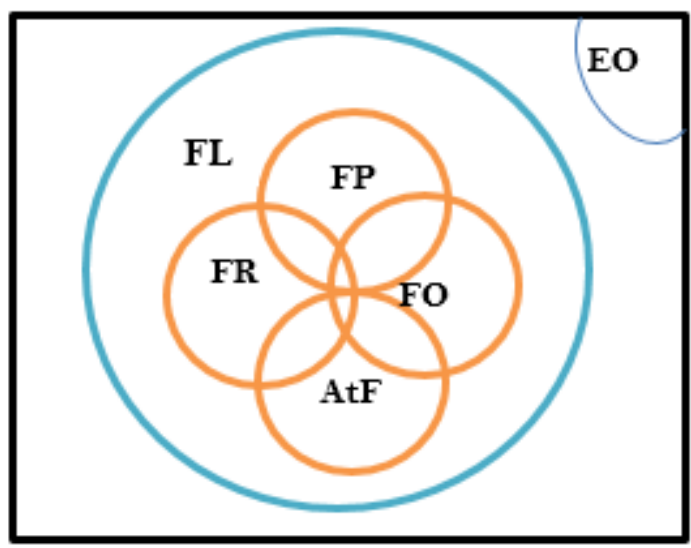

Figure 2 - Venn diagram of Financial Literature on Entrepreneurial Orientation

Further research is needed to examine the relationship between financial and entrepreneurial orientation as two key contributors to firm performance. The result of this scoping review shows that the research about financial orientation still scarce than other themes. Most of the research that we found is about financial performance and financial resources. Therefore, the opportunity to discover this theme is open widely.

\section{CONCLUSION}

The purpose of this scoping review was to spot gaps without doing an exhaustive review of the literature. One among the gaps identified associated with a scarcity of homogeneity within the theories used. The other main gap that was identified associated with a scarcity of empirical and more specifically qualitative research on financing in entrepreneurial orientation (EO) context.

Through this scoping review, we also identified multiple definitions of financial literacy within the context of EO. The lack of agreement in defining finance as a theoretical construct and therefore the lack of homogeneity in its operationalization within the research papers that were identified show both an opportunity and a challenge. The opportunity is to spot the precise financial literature within the EO context, like the relationship between financial and entrepreneurial orientation. The challenge lies in that finance as a construct may require anchoring to a specific theory to be able to define its relationship within the EO context. 
EO continues to be a vibrant field and mapping finance within this field is unexplored. This scoping study provides a launching pad for further conceptual and empirical research of finance within EO.

\section{APPENDIX}

List of 27 Research Articles on Finance Within Entrepreneurial Orientation Context

\begin{tabular}{|c|c|c|c|c|c|c|}
\hline Authors & $\begin{array}{l}\text { Publication } \\
\text { Type }\end{array}$ & Source Title & $\begin{array}{l}\text { Research } \\
\text { Question/Objective }\end{array}$ & $\begin{array}{l}\text { Type of } \\
\text { Research }\end{array}$ & $\begin{array}{l}\text { Entrepreneurial } \\
\text { Orientation as }\end{array}$ & $\begin{array}{l}\text { Financial } \\
\text { Themes } \\
\text { Covered }\end{array}$ \\
\hline $\begin{array}{l}\text { Kallmuenzer, } \\
\text { Kraus, } \\
\text { Peters, } \\
\text { Steiner, and } \\
\text { Cheng (2019) }\end{array}$ & Article & $\begin{array}{l}\text { Tourism } \\
\text { Management }\end{array}$ & $\begin{array}{l}\text { "This study investigates } \\
\text { configurations of factors } \\
\text { that lead to high firm } \\
\text { performance." (p.319) }\end{array}$ & $\begin{array}{l}\text { Sequential } \\
\text { mixed- } \\
\text { methods } \\
\text { approach }\end{array}$ & antecedent & $\begin{array}{l}\text { financial } \\
\text { resources }\end{array}$ \\
\hline $\begin{array}{l}\text { Vaznyte and } \\
\text { Andries } \\
\text { (2019) }\end{array}$ & Article & $\begin{array}{l}\text { Journal of } \\
\text { Business } \\
\text { Venturing }\end{array}$ & $\begin{array}{l}\text { "This study extends the } \\
\text { Pecking Order Theory by } \\
\text { investigating the role of } \\
\text { start-ups' strategic } \\
\text { posture for financial } \\
\text { decision-making." (p.439) }\end{array}$ & $\begin{array}{l}\text { Quantitative } \\
\text { survey } \\
\text { method }\end{array}$ & antecedent & $\begin{array}{l}\text { financial } \\
\text { resources }\end{array}$ \\
\hline $\begin{array}{l}\text { Cheah, } \\
\text { Amran and } \\
\text { Yahya (2018) }\end{array}$ & Article & $\begin{array}{l}\text { Journal of } \\
\text { Cleaner } \\
\text { Production }\end{array}$ & $\begin{array}{l}\text { "Based on the resource- } \\
\text { based view, this empirical } \\
\text { study established a } \\
\text { framework to assess the } \\
\text { influence of the most } \\
\text { prominent internal } \\
\text { oriented resources (i.e., } \\
\text { entrepreneurial } \\
\text { orientation, social salience } \\
\text { and business planning), } \\
\text { which were moderated by } \\
\text { socio-economic context, } \\
\text { towards the financial and } \\
\text { social performance of } \\
\text { social enterprises." } \\
\text { (p.607) }\end{array}$ & $\begin{array}{l}\text { Quantitative } \\
\text { survey } \\
\text { method }\end{array}$ & antecedent & $\begin{array}{l}\text { financial } \\
\text { performance }\end{array}$ \\
\hline $\begin{array}{l}\text { Arzubiaga, } \\
\text { Maseda and } \\
\text { Iturralde } \\
\text { (2018) }\end{array}$ & Article & $\begin{array}{l}\text { Australian } \\
\text { Journal of } \\
\text { Management }\end{array}$ & $\begin{array}{l}\text { "In this study, we examine } \\
\text { new drivers that generate } \\
\text { a disposition toward } \\
\text { entrepreneurial activity in } \\
\text { family firms and how the } \\
\text { strategic involvement of } \\
\text { the board of directors } \\
\text { (SIBD) moderates the } \\
\text { relationships between } \\
\text { these drivers (image of } \\
\text { the firm, willingness to } \\
\text { change, and access to } \\
\text { financial resources) and } \\
\text { entrepreneurial orientation } \\
\text { (EO)." (p.128) }\end{array}$ & $\begin{array}{l}\text { Quantitative } \\
\text { survey } \\
\text { method }\end{array}$ & consequent & $\begin{array}{l}\text { access to } \\
\text { financial } \\
\text { resources }\end{array}$ \\
\hline $\begin{array}{l}\text { Beltrame, } \\
\text { Floreani, } \\
\text { Grassetti, } \\
\text { Mason and } \\
\text { Miani (2018) }\end{array}$ & Article & $\begin{array}{l}\text { Management } \\
\text { Decision }\end{array}$ & $\begin{array}{l}\text { "The purpose of this } \\
\text { paper is to investigate } \\
\text { whether guarantees } \\
\text { characterized by different } \\
\text { degrees of relationship } \\
\text { lending (particularly } \\
\text { referring to collateral and } \\
\text { guarantees provided by } \\
\text { Mutual Loan Guarantee } \\
\text { Institutions) are able to } \\
\text { convey some } \\
\text { entrepreneurial orientation } \\
\text { (EO) dimensions from } \\
\text { firms to banks. " (p.168) }\end{array}$ & $\begin{array}{l}\text { Quantitative } \\
\text { survey } \\
\text { method }\end{array}$ & consequent & $\begin{array}{l}\text { financial } \\
\text { resources }\end{array}$ \\
\hline
\end{tabular}


List of 27 Research Articles on Finance Within Entrepreneurial Orientation Context

\begin{tabular}{|c|c|c|c|c|c|c|}
\hline Authors & $\begin{array}{l}\text { Publication } \\
\text { Type }\end{array}$ & Source Title & $\begin{array}{l}\text { Research } \\
\text { Question/Objective }\end{array}$ & $\begin{array}{l}\text { Type of } \\
\text { Research }\end{array}$ & $\begin{array}{l}\text { Entrepreneurial } \\
\text { Orientation as }\end{array}$ & $\begin{array}{l}\text { Financial } \\
\text { Themes } \\
\text { Covered }\end{array}$ \\
\hline $\begin{array}{l}\text { Purnomo } \\
\text { (2019) }\end{array}$ & Article & $\begin{array}{l}\text { Journal of } \\
\text { Enterprising } \\
\text { Communities }\end{array}$ & $\begin{array}{l}\text { "This study aims to } \\
\text { examine the relationship } \\
\text { between artistic } \\
\text { orientation and } \\
\text { entrepreneurial } \\
\text { performance and how } \\
\text { other central } \\
\text { entrepreneurial resources, } \\
\text { namely, entrepreneurial } \\
\text { orientation and financial } \\
\text { literacy, affect this } \\
\text { relationship." }\end{array}$ & $\begin{array}{l}\text { Quantitative } \\
\text { survey } \\
\text { method }\end{array}$ & antecedent & $\begin{array}{l}\text { financial } \\
\text { literacy }\end{array}$ \\
\hline $\begin{array}{l}\text { Wales, Cox, } \\
\text { Lortie and } \\
\text { Sproul (2018) }\end{array}$ & Article & $\begin{array}{l}\text { Entrepreneurship } \\
\text { Research } \\
\text { Journal }\end{array}$ & $\begin{array}{l}\text { "This study examines how } \\
\text { written expressions of } \\
\text { entrepreneurial orientation } \\
\text { (EO) and hope may affect } \\
\text { investor evaluations of } \\
\text { funding potential in } \\
\text { business plan } \\
\text { competitions." }\end{array}$ & $\begin{array}{l}\text { Conceptual } \\
\text { article }\end{array}$ & antecedent & $\begin{array}{l}\text { financial } \\
\text { resources }\end{array}$ \\
\hline $\begin{array}{l}\text { Zabelina, } \\
\text { Deyneka and } \\
\text { Tsiring (2019) }\end{array}$ & Article & $\begin{array}{l}\text { International } \\
\text { Journal of } \\
\text { Entrepreneurial } \\
\text { Behaviour and } \\
\text { Research }\end{array}$ & $\begin{array}{l}\text { "The purpose of this } \\
\text { paper is to explore how } \\
\text { students' entrepreneurial } \\
\text { attitudes are related to } \\
\text { their economic attitudes } \\
\text { regarding business, } \\
\text { investments, savings and } \\
\text { consumption." }\end{array}$ & $\begin{array}{l}\text { Quantitative } \\
\text { survey } \\
\text { method }\end{array}$ & antecedent & $\begin{array}{l}\text { financial } \\
\text { literacy }\end{array}$ \\
\hline $\begin{array}{l}\text { Brzozowski, } \\
\text { Cucculelli and } \\
\text { Peruzzi } \\
\text { (2018) }\end{array}$ & Article & $\begin{array}{l}\text { Entrepreneurship } \\
\text { Research } \\
\text { Journal }\end{array}$ & $\begin{array}{l}\text { "This paper contributes to } \\
\text { the literature on the } \\
\text { entrepreneurial behavior } \\
\text { of firms during the } \\
\text { economic crisis, by } \\
\text { investigating the } \\
\text { determinants of proactive } \\
\text { behavior on a large } \\
\text { sample of European } \\
\text { companies during the } \\
\text { 2008-2009 financial } \\
\text { crisis." }\end{array}$ & $\begin{array}{l}\text { Quantitative } \\
\text { survey } \\
\text { method }\end{array}$ & antecedent & $\begin{array}{l}\text { financial } \\
\text { resources }\end{array}$ \\
\hline $\begin{array}{l}\text { Khanagha, } \\
\text { Dehkordi, Zali } \\
\text { and Hejazi } \\
(2018)\end{array}$ & Article & $\begin{array}{l}\text { International } \\
\text { Journal of } \\
\text { Innovation and } \\
\text { Technology } \\
\text { Management }\end{array}$ & $\begin{array}{l}\text { "This paper presents the } \\
\text { initial results of a project } \\
\text { to investigate the } \\
\text { organizational } \\
\text { antecedents of } \\
\text { entrepreneurship at public } \\
\text { research and technology } \\
\text { institutions (RTIs) in Iran. } \\
\text { In line with the policies of } \\
\text { the government to } \\
\text { increase the role of } \\
\text { publicly funded R\&D in } \\
\text { solving the problems of } \\
\text { the domestic industry, the } \\
\text { research centers within } \\
\text { public RTIs are } \\
\text { encouraged to direct their } \\
\text { research efforts towards } \\
\text { practical applications, thus } \\
\text { creating value from their } \\
\text { R\&D efforts." }\end{array}$ & $\begin{array}{l}\text { Qualitative } \\
\text { One-on-One } \\
\text { Interview }\end{array}$ & antecedent & $\begin{array}{l}\text { financial } \\
\text { performance }\end{array}$ \\
\hline
\end{tabular}


List of 27 Research Articles on Finance Within Entrepreneurial Orientation Context

\begin{tabular}{|c|c|c|c|c|c|c|}
\hline Authors & $\begin{array}{l}\text { Publication } \\
\text { Type }\end{array}$ & Source Title & $\begin{array}{l}\text { Research } \\
\text { Question/Objective }\end{array}$ & $\begin{array}{l}\text { Type of } \\
\text { Research }\end{array}$ & $\begin{array}{l}\text { Entrepreneurial } \\
\text { Orientation as }\end{array}$ & $\begin{array}{l}\text { Financial } \\
\text { Themes } \\
\text { Covered }\end{array}$ \\
\hline $\begin{array}{l}\text { Adomako } \\
\text { (2017) }\end{array}$ & Article & $\begin{array}{l}\text { International } \\
\text { Journal of } \\
\text { Innovation } \\
\text { Management }\end{array}$ & $\begin{array}{l}\text { "Extant entrepreneurial } \\
\text { orientation (EO) literature } \\
\text { suggests that EO } \\
\text { positively affects firm } \\
\text { performance, but several } \\
\text { factors influence the } \\
\text { potency of this } \\
\text { relationship. However, the } \\
\text { influence of adaptive and } \\
\text { intellectual resource } \\
\text { capabilities on the EO- } \\
\text { performance linkage lacks } \\
\text { theoretical clarity. } \\
\text { Accordingly, deriving } \\
\text { insights from the } \\
\text { resource-based view and } \\
\text { dynamic capabilities } \\
\text { framework, this paper } \\
\text { argues that variations in } \\
\text { financial performance are } \\
\text { a function of the degree of } \\
\text { EO and levels of adaptive } \\
\text { and intellectual resource } \\
\text { capabilities." }\end{array}$ & $\begin{array}{l}\text { Quantitative } \\
\text { survey } \\
\text { method }\end{array}$ & antecedent & $\begin{array}{l}\text { financial } \\
\text { performance }\end{array}$ \\
\hline $\begin{array}{l}\text { Beliaeva, } \\
\text { Shirokova, } \\
\text { Wales and } \\
\text { Gafforova } \\
(2018)\end{array}$ & Article & $\begin{array}{l}\text { International } \\
\text { Entrepreneurship } \\
\text { and } \\
\text { Management } \\
\text { Journal }\end{array}$ & $\begin{array}{l}\text { "In this research, we } \\
\text { examine entrepreneurial } \\
\text { and market orientations } \\
\text { as a means through which } \\
\text { firms may operate within } \\
\text { an economic crisis to } \\
\text { seize available } \\
\text { opportunities. Additionally, } \\
\text { we consider how } \\
\text { increasing financial } \\
\text { resource availability } \\
\text { during macro-economic } \\
\text { constraint may affect } \\
\text { these relationships." (p.1) }\end{array}$ & $\begin{array}{l}\text { Quantitative } \\
\text { survey } \\
\text { method }\end{array}$ & antecedent & $\begin{array}{l}\text { financial } \\
\text { resources }\end{array}$ \\
\hline $\begin{array}{l}\text { Olutuase, } \\
\text { Brijlal, Yan } \\
\text { and } \\
\text { Ologundudu } \\
\text { (2018) }\end{array}$ & Article & $\begin{array}{l}\text { Journal of } \\
\text { Entrepreneurship } \\
\text { Education }\end{array}$ & $\begin{array}{l}\text { "In view of stimulating } \\
\text { entrepreneurial drive for } \\
\text { economic gains, it is } \\
\text { pertinent to empirically } \\
\text { unravel what } \\
\text { entrepreneurial } \\
\text { ecosystem variables } \\
\text { significantly variate } \\
\text { entrepreneurial orientation } \\
\text { and intention. Within } \\
\text { relevant theoretical } \\
\text { postulations, this article } \\
\text { aimed at determining the } \\
\text { amount of variation in } \\
\text { entrepreneurial orientation } \\
\text { and intention as caused } \\
\text { by entrepreneurial } \\
\text { ecosystem factors over } \\
\text { time. The key } \\
\text { entrepreneurial } \\
\text { ecosystem factors } \\
\text { examined include } \\
\text { business protection; } \\
\text { approval of reference } \\
\text { people; state of } \\
\text { infrastructure that } \\
\text { supports intention; ease of } \\
\text { accessing financial } \\
\text { resources; friendly } \\
\text { economic policies; and } \\
\text { increase in technology." }\end{array}$ & $\begin{array}{l}\text { Quantitative } \\
\text { survey } \\
\text { method }\end{array}$ & consequent & $\begin{array}{l}\text { access to } \\
\text { financial } \\
\text { resources }\end{array}$ \\
\hline
\end{tabular}


List of 27 Research Articles on Finance Within Entrepreneurial Orientation Context

\begin{tabular}{|c|c|c|c|c|c|c|}
\hline Authors & $\begin{array}{l}\text { Publication } \\
\text { Type }\end{array}$ & Source Title & $\begin{array}{l}\text { Research } \\
\text { Question/Objective }\end{array}$ & $\begin{array}{l}\text { Type of } \\
\text { Research }\end{array}$ & $\begin{array}{l}\text { Entrepreneurial } \\
\text { Orientation as }\end{array}$ & $\begin{array}{l}\text { Financial } \\
\text { Themes } \\
\text { Covered }\end{array}$ \\
\hline $\begin{array}{l}\text { Šarlija and } \\
\text { Pfeifer (2018) }\end{array}$ & $\begin{array}{l}\text { Conference } \\
\text { paper }\end{array}$ & $\begin{array}{l}\text { Proceedings of } \\
\text { the 32nd } \\
\text { International } \\
\text { Business } \\
\text { Information } \\
\text { Management } \\
\text { Association } \\
\text { Conference, } \\
\text { IBIMA 2018 - } \\
\text { Vision 2020: } \\
\text { Sustainable } \\
\text { Economic } \\
\text { Development } \\
\text { and Application } \\
\text { of Innovation } \\
\text { Management } \\
\text { from Regional } \\
\text { expansion to } \\
\text { Global Growth }\end{array}$ & $\begin{array}{l} \\
\text { "The aim of this paper is } \\
\text { to find out which factors } \\
\text { have direct and which one } \\
\text { indirect effect on sales } \\
\text { growth of SMEs in Croatia } \\
\text { where entrepreneurial } \\
\text { orientation is set as a } \\
\text { mediating variable." } \\
\text { (p.3170) }\end{array}$ & $\begin{array}{l}\text { Quantitative } \\
\text { survey } \\
\text { method }\end{array}$ & antecedent & $\begin{array}{l}\text { financial } \\
\text { resources }\end{array}$ \\
\hline $\begin{array}{l}\text { Bessière, } \\
\text { Gomez- } \\
\text { Breysse, } \\
\text { Messeghem, } \\
\text { Ramaroson } \\
\text { and Sammut } \\
\text { (2017) }\end{array}$ & Article & $\begin{array}{l}\text { International } \\
\text { Journal of } \\
\text { Entrepreneurship } \\
\text { and Innovation } \\
\text { Management }\end{array}$ & $\begin{array}{l}\text { "this article analyses the } \\
\text { factors that determine } \\
\text { their growth during the } \\
\text { development phase. } \\
\text { These factors are derived } \\
\text { from a resource-based } \\
\text { view (RBV) and a } \\
\text { dynamic capabilities } \\
\text { approach (DCA). " }\end{array}$ & $\begin{array}{l}\text { Quantitative } \\
\text { survey } \\
\text { method }\end{array}$ & antecedent & $\begin{array}{l}\text { financial } \\
\text { resources }\end{array}$ \\
\hline $\begin{array}{l}\text { Núñez- } \\
\text { Pomar, } \\
\text { Prado-Gascó, } \\
\text { Añó Sanz, } \\
\text { Crespo } \\
\text { Hervás, } \\
\text { Moreno } \\
(2016)\end{array}$ & Article & $\begin{array}{l}\text { Journal of } \\
\text { Business } \\
\text { Research }\end{array}$ & $\begin{array}{l}\text { "This study analyzes the } \\
\text { relationship among EO, } \\
\text { firm size, and business } \\
\text { performance of Spanish } \\
\text { sports service firms. The } \\
\text { study analyzes EO as a } \\
\text { multidimensional } \\
\text { construct (with } \\
\text { proactiveness, innovation, } \\
\text { and risk-taking } \\
\text { dimensions), and } \\
\text { business performance } \\
\text { considering self- } \\
\text { perception (perceived } \\
\text { customer satisfaction, } \\
\text { perceived market } \\
\text { effectiveness, and } \\
\text { perceived financial } \\
\text { performance) and } \\
\text { financial indicators (ROI)." } \\
\text { (p.) }\end{array}$ & $\begin{array}{l}\text { Mixed } \\
\text { method } \\
\text { (Qualitative } \\
\text { comparative } \\
\text { analysis) }\end{array}$ & antecedent & $\begin{array}{l}\text { financial } \\
\text { performance }\end{array}$ \\
\hline $\begin{array}{l}\text { Shahzad, } \\
\text { Wales, } \\
\text { Sharfman } \\
\text { and Stein } \\
(2016)\end{array}$ & Article & $\begin{array}{l}\text { Journal of } \\
\text { Management } \\
\text { and Organization }\end{array}$ & $\begin{array}{l}\text { "This study offers a } \\
\text { broader perspective on } \\
\text { the effects of } \\
\text { entrepreneurial orientation } \\
\text { beyond its well- } \\
\text { established implications } \\
\text { for firm financial } \\
\text { performance." (p.) }\end{array}$ & $\begin{array}{l}\text { Quantitative } \\
\text { survey } \\
\text { method }\end{array}$ & antecedent & $\begin{array}{l}\text { financial } \\
\text { performance }\end{array}$ \\
\hline
\end{tabular}


List of 27 Research Articles on Finance Within Entrepreneurial Orientation Context

\begin{tabular}{|c|c|c|c|c|c|c|}
\hline Authors & $\begin{array}{l}\text { Publication } \\
\text { Type }\end{array}$ & Source Title & $\begin{array}{l}\text { Research } \\
\text { Question/Objective }\end{array}$ & $\begin{array}{l}\text { Type of } \\
\text { Research }\end{array}$ & $\begin{array}{l}\text { Entrepreneurial } \\
\text { Orientation as }\end{array}$ & $\begin{array}{l}\text { Financial } \\
\text { Themes } \\
\text { Covered }\end{array}$ \\
\hline $\begin{array}{l}\text { Silver, } \\
\text { Johanson } \\
\text { and Berggren } \\
(2016)\end{array}$ & Article & $\begin{array}{l}\text { Problems and } \\
\text { Perspectives in } \\
\text { Management }\end{array}$ & $\begin{array}{l}\text { "Entrepreneurial } \\
\text { orientation is a concept } \\
\text { that captures the } \\
\text { importance of how and } \\
\text { why certain individuals } \\
\text { decide to take higher risks } \\
\text { than the average small } \\
\text { business owner so as to } \\
\text { increase their return on } \\
\text { assets deployed. } \\
\text { Entrepreneurial } \\
\text { orientation is linked to the } \\
\text { concept of control } \\
\text { aversion, which is used to } \\
\text { explain why certain } \\
\text { individuals refrain from } \\
\text { using external financing to } \\
\text { expand their firms. Control } \\
\text { aversion suggests that } \\
\text { most small business } \\
\text { owners prefer to maintain } \\
\text { total control rather than } \\
\text { invite in the potentially } \\
\text { disruptive influence of an } \\
\text { external owner/investor. } \\
\text { This study combines } \\
\text { these two concepts in an } \\
\text { attempt to introduce } \\
\text { financing and investors } \\
\text { into the discussion of } \\
\text { entrepreneurial orientation } \\
\text { and performance." (p.) }\end{array}$ & $\begin{array}{l}\text { Quantitative } \\
\text { survey } \\
\text { method }\end{array}$ & antecedent & $\begin{array}{l}\text { financial } \\
\text { resources }\end{array}$ \\
\hline $\begin{array}{l}\text { Boso, } \\
\text { Oghazi, } \\
\text { Cadogan and } \\
\text { Story (2016) }\end{array}$ & Article & $\begin{array}{l}\text { Journal of Small } \\
\text { Business } \\
\text { Strategy }\end{array}$ & $\begin{array}{l}\text { "This study examines the } \\
\text { impact of the } \\
\text { simultaneous } \\
\text { implementation of } \\
\text { entrepreneurial and } \\
\text { market-oriented export } \\
\text { activities on export } \\
\text { success and whether this } \\
\text { relationship depends on } \\
\text { levels of financial capital } \\
\text { and market environment } \\
\text { turbulence." (p.) }\end{array}$ & $\begin{array}{l}\text { Quantitative } \\
\text { survey } \\
\text { method }\end{array}$ & antecedent & $\begin{array}{l}\text { financial } \\
\text { resources }\end{array}$ \\
\hline $\begin{array}{l}\text { Ibrahim and } \\
\text { Shariff (2016) }\end{array}$ & Article & $\begin{array}{l}\text { International } \\
\text { Journal of } \\
\text { Business and } \\
\text { Society }\end{array}$ & $\begin{array}{l}\text { "The objective of this } \\
\text { study is to investigate the } \\
\text { mediating role of access } \\
\text { to finance on the positive } \\
\text { relationship between } \\
\text { entrepreneurial orientation } \\
\text { (EO), market orientation } \\
\text { (MO), learning orientation } \\
\text { (LO), technology } \\
\text { orientation (TO) and } \\
\text { SMEs performance in } \\
\text { Nigeria. " }\end{array}$ & $\begin{array}{l}\text { Quantitative } \\
\text { survey } \\
\text { method }\end{array}$ & consequent & $\begin{array}{l}\text { access to } \\
\text { financial } \\
\text { resources }\end{array}$ \\
\hline $\begin{array}{l}\text { Rank, Unger } \\
\text { and } \\
\text { Gemünden } \\
(2015)\end{array}$ & Article & $\begin{array}{l}\text { International } \\
\text { Journal of } \\
\text { Project } \\
\text { Management }\end{array}$ & $\begin{array}{l}\text { "Because of the lack of } \\
\text { research on antecedents } \\
\text { of preparedness for the } \\
\text { future in project portfolio } \\
\text { management, the present } \\
\text { study investigated } \\
\text { associations between this } \\
\text { previously neglected } \\
\text { criterion and two predictor } \\
\text { variables, namely the } \\
\text { quality of portfolio } \\
\text { management and } \\
\text { proactiveness" }\end{array}$ & $\begin{array}{l}\text { Quantitative } \\
\text { survey } \\
\text { method }\end{array}$ & Antecedent & $\begin{array}{l}\text { financial } \\
\text { resources }\end{array}$ \\
\hline
\end{tabular}


List of 27 Research Articles on Finance Within Entrepreneurial Orientation Context

\begin{tabular}{|c|c|c|c|c|c|c|}
\hline Authors & $\begin{array}{l}\text { Publication } \\
\text { Type }\end{array}$ & Source Title & $\begin{array}{l}\text { Research } \\
\text { Question/Objective }\end{array}$ & $\begin{array}{l}\text { Type of } \\
\text { Research }\end{array}$ & $\begin{array}{l}\text { Entrepreneurial } \\
\text { Orientation as }\end{array}$ & $\begin{array}{l}\text { Financial } \\
\text { Themes } \\
\text { Covered }\end{array}$ \\
\hline $\begin{array}{l}\text { Tajeddini } \\
(2015)\end{array}$ & Article & $\begin{array}{l}\text { International } \\
\text { Journal of } \\
\text { Hospitality } \\
\text { Management }\end{array}$ & $\begin{array}{l}\text { "this study explores the } \\
\text { effect of entrepreneurial } \\
\text { and financial orientations } \\
\text { as two key contributors to } \\
\text { performance in the } \\
\text { service industry." }\end{array}$ & $\begin{array}{l}\text { Quantitative } \\
\text { survey } \\
\text { method }\end{array}$ & Antecedent & $\begin{array}{l}\text { Financial } \\
\text { orientation }\end{array}$ \\
\hline $\begin{array}{l}\text { Soininen, } \\
\text { Puumalainen, } \\
\text { Sjögrén, } \\
\text { Syrjä and } \\
\text { Richter } \\
(2015)\end{array}$ & Article & $\begin{array}{l}\text { International } \\
\text { Journal of } \\
\text { Business } \\
\text { Excellence }\end{array}$ & $\begin{array}{l}\text { "Our study investigates } \\
\text { the drivers of } \\
\text { entrepreneurially oriented } \\
\text { behavior (EO) as a main } \\
\text { contributor to } \\
\text { entrepreneurship in } \\
\text { Finnish small owner- } \\
\text { managed firms. We focus } \\
\text { on the entrepreneur's } \\
\text { work values and } \\
\text { experience as an } \\
\text { entrepreneur and a firm's } \\
\text { financial slack and } \\
\text { financial conservatism." }\end{array}$ & $\begin{array}{l}\text { Quantitative } \\
\text { survey } \\
\text { method }\end{array}$ & consequent & $\begin{array}{l}\text { financial } \\
\text { resources }\end{array}$ \\
\hline $\begin{array}{l}\text { Sürer and } \\
\text { Mutlu (2015) }\end{array}$ & Article & $\begin{array}{l}\text { Journal of } \\
\text { Internet } \\
\text { Commerce }\end{array}$ & $\begin{array}{l}\text { "This article aims to } \\
\text { examine strategic } \\
\text { orientations' effects on } \\
\text { firms' performance in } \\
\text { emerging economies such } \\
\text { as Turkey. Strategic } \\
\text { orientation directly affects } \\
\text { all organizational activities } \\
\text { and behaviors. Strategic } \\
\text { orientations such as } \\
\text { market orientation (MO), } \\
\text { e-marketing orientation } \\
\text { (EMO), entrepreneurial } \\
\text { orientation (EO), and } \\
\text { technology orientation } \\
\text { (TO) are evaluated in this } \\
\text { study. EMO is explained, } \\
\text { along with its components } \\
\text { and effect on firm } \\
\text { performance, financial } \\
\text { performance (FP), and } \\
\text { marketing performance } \\
\text { (MP). EMO has two } \\
\text { components: } \\
\text { Philosophical E-marketing } \\
\text { Orientation (EMO-ph) and } \\
\text { Behavioral E-marketing } \\
\text { Orientation (EMO-behv)." }\end{array}$ & $\begin{array}{l}\text { Quantitative } \\
\text { survey } \\
\text { method }\end{array}$ & antecedent & $\begin{array}{l}\text { financial } \\
\text { performance }\end{array}$ \\
\hline $\begin{array}{l}\text { Filser, } \\
\text { Eggers, } \\
\text { Kraus, and } \\
\text { Málovics } \\
\text { (2014) }\end{array}$ & Article & $\begin{array}{l}\text { Journal of East } \\
\text { European } \\
\text { Management } \\
\text { Studies }\end{array}$ & $\begin{array}{l}\text { "This study investigates } \\
\text { the impact of financial } \\
\text { resource availability on } \\
\text { entrepreneurial orientation } \\
\text { (EO), customer orientation } \\
\text { (CO) and on growth in } \\
\text { small- and medium-sized } \\
\text { enterprises (SME) in } \\
\text { Austria and Hungary." }\end{array}$ & $\begin{array}{l}\text { Quantitative } \\
\text { survey } \\
\text { method }\end{array}$ & consequent & $\begin{array}{l}\text { financial } \\
\text { resources }\end{array}$ \\
\hline $\begin{array}{l}\text { Wales, } \\
\text { Parida, and } \\
\text { Patel (2013) }\end{array}$ & Article & $\begin{array}{l}\text { Strategic } \\
\text { Management } \\
\text { Journal }\end{array}$ & $\begin{array}{l}\text { "This study suggests an } \\
\text { inverted-U shaped } \\
\text { relationship between } \\
\text { ACAP and financial } \\
\text { performance." }\end{array}$ & $\begin{array}{l}\text { Quantitative } \\
\text { survey } \\
\text { method }\end{array}$ & antecedent & $\begin{array}{l}\text { financial } \\
\text { performance }\end{array}$ \\
\hline
\end{tabular}




\section{REFERENCES}

1. Adomako, S. 2017. The Moderating Effects of Adaptive and Intellectual Resource Capabilities on the Relationship between Entrepreneurial Orientation and Financial Performance. International Journal of Innovation Management, 22(3), art. no. 1850026.

2. Aktan, B., and Bulut, Cagri. 2008. Financial Performance Impacts of Corporate Entrepreneurship in Emerging Markets: A Case of Turkey. European Journal of Economics, Finance and Administrative Sciences, Issue 12, 69-79.

3. Arksey, H., \& O'Malley, L. 2005. Scoping studies: Towards a methodological framework. International Journal of Social Research Methodology, 8: 19-32.

4. Arzubiaga U., Maseda A., Iturralde T. 2018. Entrepreneurial orientation in family firms: New drivers and the moderating role of the strategic involvement of the board. Australian Journal Management, pp. 1-25.

5. Barte, R. 2012, Financial literacy in micro-enterprises: the case of Cebu fish vendors, Philippine Management Review, Vol. 19.

6. Beal, D. J., and Delpachitra, S. B. 2003. Financial literacy among Australian university students. Economic Papers: A Journal of Applied Economics and Policy, 22 (1): 65-78.

7. Beatty, S. 1988. An exploratory study of organizational values with a focus on people orientation. Journal Retail, 64 (4): 405-425.

8. Beliaeva T., Shirokova G., Wales W., Gafforova E. 2018. Benefiting from economic crisis? Strategic orientation effects, trade-offs, and configurations with resource availability on SME performance. International Entrepreneurship and Management Journal, pp. 1-30. doi: 10.1007/s11365-018-0499-2.

9. Berryman, J. 1983. Small business failure and survey of the literature. European Small Business Journal, 1 (4): 47-59.

10. Burgelman, R.A., \& Valikangas, L. 2005. Managing internal corporate venturing cycles. MIT Sloan Management Review, 46 (4): 26-34.

11. Chandler, G. N., McEvoy, G. M. 2000. Human resource management, TQM, and firm performance in small and medium-sized enterprises. Entrepreneurship Theory and Practice, 25: 43-58.

12. Cheah J, Amran A, Yahya S. 2018. Internal oriented resources and social enterprises' Performance: How can social enterprises help themselves before helping others?, Journal of Cleaner Production, https://doi.org/10.1016/j.jclepro.2018.11.203.

13. Covin, J. G., \& Slevin, D. P. 1988. The influence of organization structure on the utility of an entrepreneurial top management style. Journal of Management Studies, 25(3), 217234.

14. Covin, J. G., Green, K. M., \& Slevin, D. P. 2006. Strategic process effects on the entrepreneurial orientation-sales growth rate relationship. Entrepreneurship Theory and Practice, 30(1), 57-81.

15. Cruz, C., \& Nordqvist, M. 2012. Entrepreneurial orientation in family firms: a generational perspective. Small Business Economics, 38(1), 33-49.

16. Davis, K., Drey, N., \& Gould, D. 2009. What are scoping studies? A review of the nursing literature. International Journal of Nursing Studies, 46, 1386-1400. DOI:10.1016/j. ijnurstu.2009.02.010.

17. De Meza, D., and Southey, C. 1996. The borrower's curse: Optimism, finance and entrepreneurship. The Economic Journal, 106: 375-386.

18. Eisenmann, T. R. 2006. Internet companies' growth strategies: Determinants of investment intensity and long-term performance. Strategic Management Journal, 27 (12): 1183-1204.

19. Fatoki, O. 2012. The Impact of Entrepreneurial Orientation on Access to Debt Finance and Performance of Small and Medium Enterprises in South Africa. Journal of Social Science, 32(2), 121-131.

20. Filser M., Eggers F., Kraus S., Málovics É. 2014. The effect of financial resource availability on entrepreneurial orientation, customer orientation and firm performance in 
an international context: An empirical analysis from Austria and Hungary. Journal of East European Management Studies, 19 (1): 7-30.

21. Frank, H., Kessler, A., \& Fink, M. 2010. Entrepreneurial orientation and business performance-a replication study. Schmalenbach Business Review, 62, 175-198.

22. Fritz, W., 1996. Market orientation and corporate success: findings from Germany. European Journal Market, 8, 59-74.

23. George, G., 2005. Slack resources and the performance of privately held firms. Academy of Management Journal, 48: 661-676.

24. Hughes, M., Hughes, P., Morgan, R.E. 2007. Exploitative learning and entrepreneurial orientation alignment in emerging young firms: Implications for market and response performance. British Journal of Management, 18(4), pp. 359-375.

25. Hussain, J., Ismail, K., Akhtar, C.S. 2015. Linking entrepreneurial orientation with organizational performance of small and medium sized enterprises: A conceptual approach. Asian Social Science, 11(7), 10 p.

26. Huston, S.J. 2010. Measuring financial literacy. The Journal of Consumer Affairs, Vol. 44 No. 2, pp.296-316.

27. Kallmuenzer A., Kraus S., Peters M., Steiner J., Cheng C.-F. 2019. Entrepreneurship in tourism firms: A mixed-methods analysis of performance driver configurations. Tourism Management, 74: 319-330.

28. Khalili, H., Nejadhussein, S. And Fazel, A. 2013. The influence of entrepreneurial orientation on innovative performance: study of a petrochemical company in Iran. Journal of Knowledge-based Innovation, 5 (3), pp. 262-278. https://doi.org/10.1108/JKIC-0920130017.

29. Kim, J. 2001. Financial knowledge and subjective and objective financial well-being. Consumer Interests Annual, 47: 1-3.

30. Lee, S. M., \& Peterson, S. J. 2001. Culture, entrepreneurial orientation, and global competitiveness. Journal of world business, 35(4), 401-416.

31. Lumpkin, G.T. and Dess, G.G. 1996. Clarifying the entrepreneurial orientation construct and linking it to performance. Academy of Management Review, 21 (1): 135-172.

32. Lusardi, A. and Mitchell, O.S. 2014. The economic importance of financial literacy: theory and evidence. Journal of Economic Literature, 52 (1): 5-44.

33. Masterson, R., Pickton, D., 2004. Marketing: An Introduction. McGraw Hill, London.

34. McCarthy, S., Oliver, B., and Verreynne, M. L. 2017. Bank financing and credit rationing of Australian SMEs. Australian Journal of Management 42: 58-85.

35. Miller, D. 1983. The Correlates of Entrepreneurship in Three Types of Firms. Management of Science.

36. Muzanai, M., and Fatoki, O. 2012. Perceptions of Start-up Small and Medium-Sized Enterprises (SMEs) on the importance of Business Development Services Providers (BDS)on Improving Access to Finance in South Africa. Journal of Social Science, 30 (1): 31-41.

37. Núñez-Pomar J., Prado-Gascó V., Añó Sanz V., Crespo Hervás J., Calabuig Moreno F. 2016. Does size matter? Entrepreneurial orientation and performance in Spanish sports firms. Journal of Business Research, 69 (11): 5336-5341.

38. Noctor, M., Stoney, S. and Stradling, R. 1992. 'Financial Literacy: a Discussion of Concepts and Competencies of Financial Literacy and Opportunities for Its Introduction into Young People's Learning', National Foundation for Educational Research, London.

39. Purnomo B.R. 2019. Artistic orientation, financial literacy and entrepreneurial performance. Journal of Enterprising Communities. https://doi.org/10.1108/JEC-09-20180065.

40. Wiklund, J. and Shepherd, D. 2005. Entrepreneurial Orientation and Small Business Performance: A Configurational Approach. Journal of Business Venturing, 20, 71-91. https://doi.org/10.1016/j.jbusvent.2004.01.001.

41. Rank J., Unger B.N., Gemünden H.G. 2015. Preparedness for the future in project portfolio management: The roles of proactiveness, riskiness and willingness to cannibalize. International Journal of Project Management, 33 (8): 1730-1743. 
42. Shahzad A.M., Wales W.J., Sharfman M.P., Stein C.M. 2016. Casting a wider performance net: The role of entrepreneurial orientation in boosting overall firm stakeholder value. Journal of Management and Organization, 22 (2): 272-290.

43. Servon, L.J. and Kaestner, R. 2008, Consumer financial literacy and the impact of online banking on the financial behavior of lower-income bank customers. Journal of Consumer Affairs, 42 (2): 271-305.

44. Siekei, J., Wagoki, J. and Kalio, A. 2013. An assessment of the role of financial literacy on performance of small and micro enterprises: case of equity group foundation training program on SMEs in Njoro district, Kenya. Business and Applied Sciences, 1, p.250.

45. Silver L., Johanson M., Berggren B. 2016. Entrepreneurial orientation, control aversion and performance in SMEs: The contribution of equity investors. Problems and Perspectives in Management, 14 (3): 55-64.

46. Soininen J., Puumalainen K., Sjögrén H., Syrjä P., Richter C. 2015. What drives entrepreneurial orientation in small firms? The roles of owner-manager and financial conditions. International Journal of Business Excellence, 8 (1): 85-103.

47. Sürer A., Mutlu H.M. 2015. The Effects of an E-marketing Orientation on Performance in Turkish Exporter Firms. Journal of Internet Commerce, 14 (1): 123-138.

48. Tajeddini K. 2015. Exploring the antecedents of effectiveness and efficiency. International Journal of Hospitality Management, 49: 125-135.

49. Treacy, M., Wiersema, F. 1993. Customer intimacy and other value disciplines. Harvard Business, Rev.71 (January-February), 84-93.

50. Vaznyte, E., Andries, P. 2019. Entrepreneurial orientation and start-ups' external financing. Journal of Business Venturing, 34 (3): 439-458.

51. Venkatraman N. and Ramanujam V. 1986. Measurement of Business Performance in Strategy Research: A comparison of Approaches. The Academy of Management Review 11(4):801-814.

52. Wales W., Cox K.C., Lortie J., Sproul C.R. 2019. Blowing Smoke? How Early-Stage Investors Interpret Hopeful Discourse within Entrepreneurially Oriented Business Plans. Entrepreneurship Research Journal, 9 (3). Doi: 10.1515/erj-2018-0114.

53. Weismeier-Sammer, D. 2011. Entrepreneurial behavior in family firms: A replication study. Journal of Family Business Strategy, 2(3), 128-138.

54. Wise, S. 2013. The impact of financial literacy on new venture survival. International Journal of Business and Management, 8, p.30.

55. Zabelina E., Deyneka O., Tsiring D. 2019. Entrepreneurial attitudes in the structure of students' economic minds. International Journal of Entrepreneurial Behaviour and Research. Doi: 10.1108/lJEBR-04-2018-0224.

56. Zampetakis, Leonidas A., Vekini, Melina and Moustakis, Vassilis. 2011. Entrepreneurial Orientation, access to financial resources and product performance in the Greek commercial TV industry. The Service Industries Journal, 31 (6), 897-910. http://dxdoi.org/10.1080/02642060902960800. 